\title{
Article/Artigo
}

\section{Molecular characterization of rabies virus isolated from non- haematophagous bats in Brazil}

\section{Caracterização molecular do vírus da raiva isolado de morcegos não-hematófagos no Brasil}

\author{
Avelino Albas ${ }^{1}$, Angélica Cristine de Almeida Campos², Danielle Bastos Araujo ${ }^{2}$, Camila Seabra Rodrigues ${ }^{2}$, \\ Miriam Martos Sodré ${ }^{3}$, Edison Luiz Durigon ${ }^{2}$ and Silvana Regina Favoretto ${ }^{2,4}$
}

\begin{abstract}
Introduction: Rabies is an important zoonosis that causes thousands of deaths worldwide each year. Although the terrestrial cycle, mainly transmitted by dogs, is controlled in Brazil, the aerial cycle remains a serious public health issue, besides the economic problem. In the aerial cycle, the haematophagous bat Desmodus rotundus is the main source of infection, where several different species of non-haematophagous bats can be infected and can transmit the virus. Methods: The aim of this work was to study the epidemiological pattern of rabies using antigenic characterization with monoclonal antibodies and genetic characterization by reversetranscriptase polymerase chain reaction followed by sequencing and phylogenetic analysis of non-haematophagous bats' and herbivorous animals' central nervous system samples from the western region of the State of São Paulo, Brazil. Results: From 27 samples, 3 antigenic variants were identified: AgV-3, AgV-4, and AgV-6; and from 29 samples, 5 different clusters were identified, all belonging to the rabies virus species. Conclusions: Although only nonhaematophagous bats were evaluated in the studied region, the majority of samples were from antigenic and genetic variants related to haematophagous bats Desmodus rotundus. Samples from the same antigenic variant were segregated in more than one genetic cluster. This study demonstrated the diversity of rabies virus genetic lineages presented and circulating in nonhaematophagous bats in the studied region.
\end{abstract}

Keywords: Rabies. Bats. Antigenic characterization. Genetic characterization.

\section{RESUMO}

Introdução: A raiva é uma importante zoonose responsável por milhares de mortes anualmente em todo o mundo. Embora o ciclo silvestre, onde os cães são os principais transmissores esteja controlado no Brasil, o ciclo aéreo, onde o morcego hematófago Desmodus rotundus é o principal transmissor e diversas espécies de morcegos não hematófagos podem se infectar e transmitir o vírus, permanence como um importante problema econômico e de saúde pública. Métodos: O objetivo deste trabalho foi a caracterização antigênica por meio da utilização de anticorpos monoclonais e a caracterização genética por meio da reação em cadeia pela polimerase pela transcriptase reversa seguida de análise filogenética em morcegos não hematófagos e animais domésticos herbívoros provenientes da região oeste do Estado de São Paulo. Resultados: A análise antigênica de 27 amostras determinou três variantes distintas: Agv-3, AgV-4 e AgV-6; a análise genética de 29 amostras identificou 5 diferentes grupos, todos pertencentes a espécie Rabies virus. Conclusões: Ainda que apenas amostras de morcegos não hematófagos tenham sido analisadas, a maioria das variantes antigênicas e genéticas identificadas na região estava relacionada com a variante mantida pelos morcegos hematófagos Desmodus rotundus. Amostras de uma mesma variante antigênica segregaram em mais de um clado genético. Este estudo demonstrou a diversidade de linhagens genéticas do vírus da raiva presentes e circulantes em morcegos não hematófagos na região estudada.

Palavras-chaves: Raiva. Morcegos. Caracterização antigênica. Caracterização genética.

1. Pólo da Alta Sorocabana, Agência Paulista de Tecnologia de Agronegócios Presidente Prudente, SP. 2. Núcleo de Pesquisas em Raiva, Laboratório de Virologia Clínica e Molecular, Instituto de Ciências Biomédicas, Universidade de São Paulo, São Paulo, SP. 3. Laboratório de Zoonoses e Doenças Transmitidas por Vetores, Centro de Controle de Zoonoses, Prefeitura Municipal de São Paulo, São Paulo, SP. 4. Laboratório de Diagnóstico, Instituto Pasteur de São Paulo, São Paulo, SP.

Address to: Dra. Silvana Regina Favoretto. Av. Prof. Lineu Prestes 1374/225, 05508-030 São Paulo, SP, Brasil.

Phone: 5511 3091-7293

e-mail: srfavoretto@usp.br

Received in 09/05/2011

Accepted in 17/06/2011

\section{INTRODUCTION}

Rabies is an infectious disease responsible for more than 55,000 deaths worldwide and 15 million post-exposure treatments annually; this is despite the existence of effective vaccines for human and veterinary use $\mathrm{e}^{1}$. Rabies remains to be a serious public health concern and a cause of serious economic and environmental problems. Rabies virus, a neurotropic virus from the Lyssavirus genus, Rhabdoviridae family, is the agent of the disease $\mathrm{e}^{2-3}$. The disease is widespread and is found in all continents except Antartica ${ }^{1}$. All mammals are susceptible to rabies virus, mainly the Carnivora and Chiroptera orders. Dogs and, occasionally, cats are mainly responsible for the transmission of urban rabies; and in sylvatic rabies, the major host is a different species of wild mammals in different regions of the world ${ }^{4}$.

Although dogs remain as the principal source of rabies infection to humans, several countries, including Brazil, have been able to control this cycle of the disease ${ }^{5}$. However, rabies virus still circulates in several species of wild mammals that can infect domestic animal species and humans ${ }^{1,6-7}$.

In terms of wild mammal hosts, bats are the main reservoirs of rabies virus, and cases of rabies caused by accidents with different bat species have been reported worldwide in the past decades. In Latin America, the haematophagous bat Desmodus rotundus is the major responsible for the aerial cycle with important role in the transmission of the disease to livestock animals ${ }^{8}$ as well as the critical source of infection to human rabies ${ }^{9-11}$. Aggression by Desmodus rotundus is currently the main cause of human rabies in Brazil, and a great number of rabies cases on nonhaematophagous bat species have been diagnosed, although with no human cases $^{5}$. Bat rabies, combined with recent aggression by wild canines (Cerdocyon thous) and marmosets (Callithrix jacchus) ${ }^{12-13}$, points out to the importance of a continuous vigilance in wild animals; to understand the epidemiology of the disease in those species and to establish adequate strategies of prevention and control. 
The region of Presidente Prudente (Lat. 22 $07^{\prime} 32^{\prime \prime}$; Lon. $51^{0} 23^{\prime} 20^{\prime \prime}$ ) is located in the Western region of the State of São Paulo, Brazil. The terrestrial cycle the rabies transmitted by dogs is controlled in the state, but the aerial cycle, where bats are the source of infection, remains a serious issue, also in the studied region. The number of notified rabies cases in the state of São Paulo in 2010 was 32 in cattle (all due to related with bats), two in haematophagous bats, and 54 in non-haematophagous bats 5 . These data confirm the importance of the knowledge of the antigenic and genetic patterns of rabies in nonhaematophagous bats in the region.

The aim of the present study was the determination of the antigenic and genetic profiles of rabies virus circulation in the Western region of the State of São Paulo, Brazil, using antigenic and genetic characterization of samples from non-haematophagous bat species and herbivorous animals.

\section{METHODS}

All techniques were carried out according to Biosafety Proceedings Standards at the Centers for Rabies Research (NPR) in the Level 3 Biosafety Laboratory of the Clinical and Molecular Laboratory, Institute of Biomedical Sciences II (ICB II), University of São Paulo (USP), Brazil.

\section{Samples}

The studied samples were from the Polo da Alta Sorocabana Laboratory, in the City of Presidente Prudente, Western region of the State of São Paulo, Brazil.

All samples were previously diagnosed as rabies virus positive by fluorescent antibodies test (FAT) ${ }^{14}$ and mouse inoculation test $(\mathrm{MIT})^{15}$ techniques; 24 samples were from non-haematophagous bat species, five from cattle, and one from horse.

Samples were submitted to virus amplification by inoculation on swiss albine mouse brains, identified, and stored at $-70^{\circ} \mathrm{C}$ on the NPR sample bank. A sample of the standard rabies virus (brcvsusp47/05), maintained in BHK-21 cell culture, was used as positive control, and non-infected mouse brain served as negative control.

\section{Antigenic characterization with monoclonal antibodies}

A panel of eight monoclonal antibodies against rabies virus nucleoprotein was used. The panel was produced by the Centers for Disease Control and Prevention (CDC), Atlanta, GA, USA, and pre-established for characterization of American rabies isolates by the Pan American Health Organization (PAHO) ${ }^{7}$.

The panel allows the identification of different reactivity patterns, related with the maintenance and transmission of rabies virus. The indirect immunofluorescence test to determine the antigenic variants was performed according to the protocol described by Favoretto et al. ${ }^{12}$

\section{Reverse transcriptase-polymerase chain reaction}

Total RNA Extraction: fragments of brain samples were macerated with $500 \mathrm{uL}$ of $\mathrm{DEPC}^{\circ} \mathrm{H}_{2} \mathrm{O}$, and the RNA was obtained by using the Trizol LS Reagent (Invitrogen Corporation, Carlsbad, CA) following the manufacturer's instructions.

Primers: reverse transcriptase-polymerase chain reaction (RT-PCR) wasperformed with the primers $21 \mathrm{~g}$ (5'ATGTAACACCTCTACAATG 3', nt 55-73), 304 (5' TTGACGAAGTCTTGCTCAT 3' nt 15331514'), and SeqN (5'GGCACAGTWGTCACTGCT 3', nt 749-766) specifically designed to amplify the gene responsible for rabies virus nucleoprotein transcription, by Smith et al. ${ }^{16}$ and Campos et al. ${ }^{17}$ manufactured by Invitrogen custom primers.

Reverse transcriptase polymerase chain reaction: the RT-PCR was conducted according to the protocol described by Campos et al. ${ }^{17}$, with modifications.

Four $\mu \mathrm{L}$ of the extracted RNA was added to a mix containing $8 \mu \mathrm{L}$ of enzyme buffer, $1 \mu \mathrm{L}$ of $10 \mathrm{mM}$ dNTP Mix, $5 \mu \mathrm{L}$ of the primers $21 \mathrm{G}$ and $304(10 \mathrm{pmol} / \mathrm{uL}), 04 \mathrm{mM} \mathrm{DTT}, 40 \mathrm{U}$ of ribonuclease inhibitor (RNAse out - Invitrogen Corporation, Carlsbad, CA), 200U of reverse transcriptase-Moloney murine leukemia virus/super script and $\mathrm{H}_{2} \mathrm{O}$ DEPC. The reaction was incubated at $42^{\circ} \mathrm{C}$ for $60 \mathrm{~min}$.

The cDNA obtained was added to a mix containing $10 \mathrm{x}$ reaction buffer, $2 \mu \mathrm{M}$ of $\mathrm{MgCl}_{2}, 200 \mu \mathrm{M}$ of each dNTP, $50 \mathrm{pmol}$ of the primers SeqN and 304, 2.5U of TaqDNA polymerase and $\mathrm{H}_{2} \mathrm{O}$ DEPC ${ }^{\circ}$ to a final volume of $50 \mu \mathrm{L}$.

Amplification was carried out using the following cycle: samples were preheated for $5 \mathrm{mins}$. at $95^{\circ} \mathrm{C}$ followed by 35 cycles of denaturation for $45 \mathrm{~s}$ at $94^{\circ} \mathrm{C}$, primer annealing for $45 \mathrm{~s}$ at $45^{\circ} \mathrm{C}$, primer extension for $90 \mathrm{~s}$ at $72^{\circ} \mathrm{C}$, and a final primer extension for $5 \mathrm{~min}$ at $72^{\circ} \mathrm{C}$ in a Gradient Thermocycler (Eppendorf - Germany). All reactions were made with positive and negative controls.

The amplified products were analyzed by eletrophoresis in agarose gel $1.5 \%$ in TBE $1 x$ buffer and ethydium bromide. The results were compared with positive and negative controls and a DNA ladder of $100 \mathrm{bp}$. Positive fragments presented 765bp.

\section{Sequencing and genetic analysis}

The nucleotide sequences obtained were edited and aligned using the ClustalW ${ }^{18}$ and BioEdit v7.0.9 - Sequence Aligment Editor (1197-2007, Tom Hall, Ibis Biosciences Carlsbad, CA) programs, based in homologous sequences available in GenBank. For the similarity analysis, 320 base pairs, between the 1,157 and 1,476 positions, correspondent to the carboxyl-terminal portion of the nucleoprotein gen, were used.

Determination of the genetic distance and reconstruction of phylogenetic trees were made using MEGA Program 4.0 version ${ }^{19}$ and Kimura 2-parameters and neighbor-joining methods for topology reconstruction. The determination of the topology reliability in the phylogenetic analysis was conducted with the bootstrap probability values calculus, by using 10,000 replicas.

\section{RESULTS}

\section{Antigenic characterization}

Out of the 30 samples, 27 were antigenically characterized ( 21 bats being 11 from frugivorous bats, nine from insectivorous bats, and one from nectivorous; five cattle and one horse). Three antigenic variants were identified (Table 1).

The antigenic variants $3(\mathrm{AgV}-3)$, related to populations of haematophagous bats Desmodus rotundus, was observed in $71.4 \%$ $(15 / 21)$ of the bats and $100 \%(5 / 5)$ of the cattle and horse $(1 / 1)$. $\mathrm{AgV}-3$ was also identified in $90.9 \%(10 / 11)$ of the frugivorous bats Artibeus lituratus and 55.6\% (5/9) of the insectivorous bats (three Lasiurus ega, one Molossus molossus, and one Lasiurus blossevillii).

The AgV-4 variant, related to populations of insectivorous bats Tadarida brasiliensis, was observed in three insectivorous bats (two Eptesicus furinalis and one Myotis nigricans) and one frugivorous bat Artibeus lituratus. 
TABLE 1 - Antigenic variants and genetic lineages observed by host.

\begin{tabular}{|c|c|c|c|c|c|}
\hline \multicolumn{2}{|c|}{ Genetic } & \multirow[b]{2}{*}{ Antigenic variant } & \multirow[b]{2}{*}{ Host } & \multirow[b]{2}{*}{ Identification USP } & \multirow[b]{2}{*}{ Identification } \\
\hline Group & Lineage & & & & \\
\hline \multirow[t]{22}{*}{1} & Related to Desmodus rotundus & & Artibeus lituratus & bralusp041/05 & $537 / 04$ \\
\hline & & & Artibeus lituratus & bralusp047/07 & $438 / 04$ \\
\hline & & & Artibeus lituratus & bralusp042/07 & $474 / 04$ \\
\hline & & & Artibeus lituratus & bralusp049/07 & $397 / 04$ \\
\hline & & & Artibeus lituratus & bralusp050/07 & $496 / 04$ \\
\hline & & $\mathrm{AgV}-3$ & Artibeus lituratus & bralusp052/07 & $551 / 03$ \\
\hline & & & Artibeus lituratus & bralusp062/07 & $256 / 05$ \\
\hline & & & Artibeus lituratus & bralusp069/07 & $305 / 07$ \\
\hline & & & Artibeus lituratus & bralusp071/07 & $308 / 07$ \\
\hline & & & Artibeus lituratus & bralusp001/08 & $062 / 08$ \\
\hline & & Not performed & Eptesicus furinalis & brefusp011/09 & $224 / 09$ \\
\hline & & Not performed & Glossofaga soricina & brgsusp063/07 & $202 / 07$ \\
\hline & & & Lasiurus blossevillii & brlbusp036/07 & 045/04 \\
\hline & & & Lasiurus ega & brleusp034/07 & $116 / 04$ \\
\hline & & & Lasiurus ega & brleusp048/07 & $056 / 06$ \\
\hline & & & Lasiurus ega & brleusp055/07 & $565 / 05$ \\
\hline & & & Molossus molossus & brmmusp043/07 & $991 / 03$ \\
\hline & & $\mathrm{AgV}-3$ & Bos taurus & brbvusp044/07 & $058 / 05$ \\
\hline & & & Bos taurus & brbvusp056/07 & $637 / 03$ \\
\hline & & & Bos taurus & brbvusp003/08 & $230 / 08$ \\
\hline & & & Bos taurus & brbvusp004/08 & $263 / 08$ \\
\hline & & & Bos taurus & brbvusp006/08 & $692 / 07$ \\
\hline Not performed & Not performed & $\mathrm{AgV}-3$ & Equus caballus & brhrusp005/08 & $657 / 07$ \\
\hline 2 & Related to Tadarida brasiliensis & $\mathrm{AgV}-4$ & Artibeus lituratus & bralusp054/07 & $241 / 05$ \\
\hline \multirow[t]{2}{*}{3} & Related to insectivorous bats & Not performed & Myotis nigricans & brmnusp058/07 & $819 / 04$ \\
\hline & & $\mathrm{AgV}-4$ & Myotis nigricans & brmnusp061/07 & $367 / 06$ \\
\hline \multirow[t]{3}{*}{4} & & $\mathrm{AgV}-4$ & Eptesicus furinalis & brefusp064/07 & $111 / 07$ \\
\hline & & & Eptesicus furinalis & brefusp008/09 & $147 / 09$ \\
\hline & & & Eptesicus furinalis & brefusp009/09 & 199/09 \\
\hline 6 & Related to Lasiurus cinereus & $\mathrm{AgV}-6$ & Lasiurus blossevillii & brlblusp040/07 & $032 / 06$ \\
\hline
\end{tabular}

USP: Universidade de São Paulo; AgV: antigenic variant.

The AgV-6 variant, related to populations of insectivorous bat Lasiurus cinereus, was observed in one Lasiurus blossevillii insectivorous bat.

\section{Genetic characterization}

From the 30 samples, 29 ( 24 bats, five cattle) were genetically characterized through nucleotide sequence. All samples were characterized as Rabies virus specie, Lyssavirus genus.

The reconstruction of the phylogenetic tree, with samples from the studied region and from GenBank, revealed the presence of six clusters: group 1 to group 6; the average intrinsic distance within group was from $0.8 \%$ to $50 \%$, and the average intrinsic distance among the six groups was from $11 \%$ to $21.9 \%$.

Group 1, genetically related to the haematophagous bat Desmodus rotundus (Figure 1), presented 22 viral isolates: 5 samples from bovines and 17 from bats; 10 from frugivorous bats Artibeus lituratus, 6 from insectivorous bats (one Lasiurus blossevillii, one Molossus molossus, one Eptesicus furinalis, three Lasiurus ega), and one from nectivorous bat Glossofaga soricina. The average intrinsic distance within group of this cluster was $3 \%$, and the average intrinsic distance between groups ranged from $11 \%$ with group 2 and $20.7 \%$ with group 6 .
Group 2 presented only one sample from the frugivorous bat Artibeus lituratus; this sample was segregated with the genetic variant maintained by the Tadarida brasiliensis bat. The average intrinsic distance within group was $0.8 \%$, and the average intrinsic distance between groups ranged from $11 \%$ with group 1 and $18.5 \%$ with group 3 .

In group 3, two Myotis nigricans insectivorous bats were segregated with samples from this bat species, with an average intrinsic distance within group of $3 \%$ and average intrinsic distance between groups ranging from $16 \%$ with group 4 and $21.9 \%$ with group 6 .

Group 4 presented three samples from Eptesicus furinalis insectivorous bats, segregating with two different species of insectivorous bats (Eumops auripendulus and Nyctinomops laticaudatus) and with samples of the same species and one sample of an Artibeus lituratus frugivorous bat isolated in a different region in the State of São Paulo. This group presented an average intrinsic distance of $1.6 \%$ within group, and the average intrinsic distance between groups ranged from $12.9 \%$ with group 5 and $20.3 \%$ with group 6 .

Group 5 is represented by samples from Eptesicus furinalis bats from a different region in the State of São Paulo, about 400 miles away from the studied region, and none of the studied samples were segregated with this cluster. 


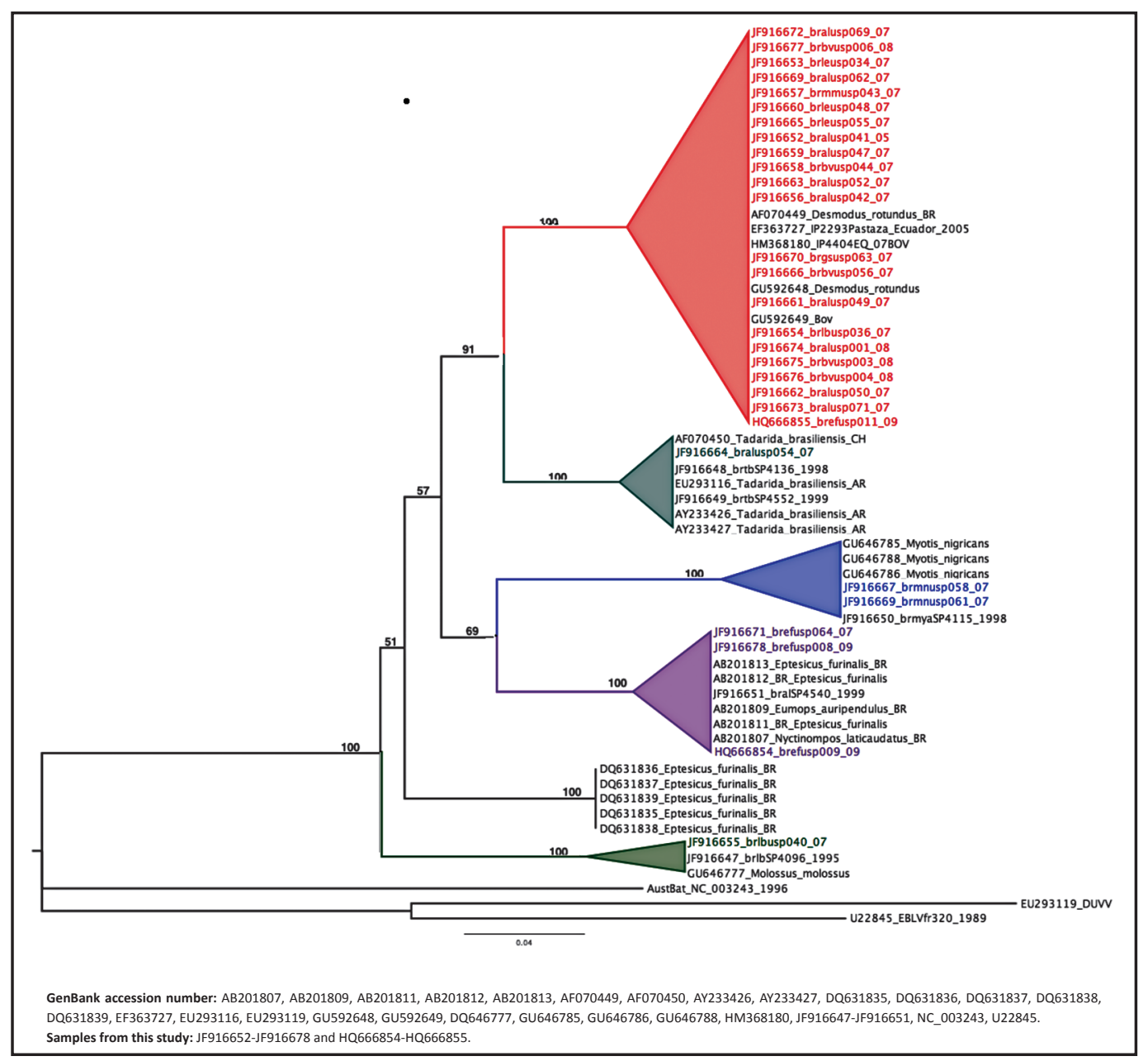

FIGURE 1 - Phylogenetic tree with maximum likelihood reconstructed with MEGA4. Bootstrap values obtained with 10,000 replicas.

Group 6 was segregated with one sample from one insectivorous bat Lasiurus blossevillii antigenic characterized as AgV-6 and samples from Brazilian insectivorous bats Molossus molossus and Lasiurus blossevillii. The average intrinsic distance within group was $5 \%$, and the average intrinsic distance between groups ranged from $16.6 \%$ with group 5 and $21.9 \%$ with group 3 .

\section{DISCUSSION}

The monoclonal antibodies technique allows the characterization of rabies antigenic variants and possible reservoirs of the virus ${ }^{12}$. Among the 27 samples submitted for antigenic analysis, three antigenic variants were identified, all belonging to profiles from the existent panel and previously identified in Latin America by several authors ${ }^{12,20-22}$. These variants represent rabies virus reservoirs from Latin America maintained by Desmodus rotundus (AgV-3), Tadarida brasiliensis (AgV-4), and Lasiurus cinereus (AgV-6) bat populations.

Besides the bats isolates, 6 herbivorous (five cattle and one horse) rabies positive samples were also typed; all were related to the rabies virus variant maintained by the haematophagous bat Desmodus rotundus. This bat species is the main source of infection for herbivorous animals.

The genetic lineage of 29 samples was determined by molecular biology techniques considering the carboxyl-terminal portion of the nucleoprotein gene, as previously described by Kissi et al. ${ }^{23}$ for these studies. All samples belonged to the Lyssavirus genus, Rabies virus species. The reconstruction of the phylogenetic tree, with samples from the studied region, demonstrated that all segregated with samples available at GenBank and representative of genetic lineages related to bats species already identified ${ }^{24-27}$. The observed clusters were supported by high bootstrap values (91\% to $100 \%$ ).

The fact that genetic variant related to haematophagous bats was identified in $75.8 \%(22 / 29)$ of the studied samples, those samples from group 1 confirmed the results obtained with the antigenic characterization as $\mathrm{AgV}-3$. This variant was also found in $90.9 \%$ of the frugivorous bats Artibeus lituratus, 50\% of the insectivourous bats (one Lasiurus blossevillii, one Molossus molossus, one Eptesicus furinalis, and three Lasiurus ega), and the nectivorous bat Glossofaga soricina. Those results were also related in studies with samples isolated from bats from the State of São Paulo and other Brazilian regions ${ }^{26-27}$.

Epidemiological studies with samples isolated from bat species in Brazil are very rare. To compare results, only the region until the stop codon of the nucleoprotein gene was considered, as also described by Oliveira et al. ${ }^{25}$ One sample from an Artibeus lituratus frugivorous bat was segregated with samples related to the genetic lineage maintained by Tadarida brasiliensis bats. This substitution was observed in one tyrosine found in the Pasteur Virus (PV) sample (NC 001542) by asparagine in Brazilian samples ${ }^{25}$; this substitution was also observed in the studied samples that were segregated in this cluster. This group presented the lowest average intrinsic distance within group.

The genetic lineage identified in the samples from group 3 was previously related ${ }^{25}$ to the Myotis bat genus. The same research group 
described the substitution of the glutamic acid in the 368 position of the PV sample by aspartic acid in Myotis bats samples ${ }^{25}$ as observed in this cluster.

In group 4, the average intrinsic distance within group was $1.6 \%$, a small distance, but the samples from this study (all from Eptesicus furinalis) were segregated with three different bat species (two insectivorous and one frugivorous). This cluster presented two substitutions: one at 367 position from glutamine to lysine and another at 433 position from alanine to serine; these substitutions were also observed by Oliveira et $a .^{25}$. However, the amino acid substitution was founded the role in the pathogenesis, and viral entry is unknown and should be the objective of future studies.

In all groups, one conserved serine was observed in the phosphorylation site (389 position of the PV sample) as previously described ${ }^{25,28}$.

None of the studied samples were segregated with the group formed by Eptesicus furinalis isolated from a different region in São Paulo, 400 miles away from the studied region, described by Almeida et al. ${ }^{29}$ and named as group 5. However, several studied samples of rabies virus were isolates from the same bat species.

One sample from the Lasiurus blossevillii bat antigenically characterized as AgV-6 (related to variants maintained by Lasiurus cinereus) was segregated in a group formed by bats of this genus and one Molossus molossus. The genetic characterization confirmed the antigenic characterization result, and group 6 presented an average intrinsic distance within group of $5 \%$.

Although samples presented the same antigenic profile characterized as AgV-4, in the genetic characterization, these samples were segregated in three different groups with average intrinsic distance between groups ranging from $16 \%$ to $18.5 \%$.

The antigenic characterization performed during the study demonstrated three different antigenic variants circulating in the studied region: one maintained by haematophagous bat and two by insectivorous bats. However, five samples from four insectivorous bat species (three Eptesicus furinalis and one Myotis nigricans) and one fugivorous (Artibeus lituratus), antigenically characterized as AgV-4, were segregated in three different clusters: one related to the rabies virus maintained by Tadarida brasiliensis and two related to virus isolates from insectivorous bats. Those results indicate the low resolution of the monoclonal antibodies panel for genetic lineages circulating in Brazilian bat populations. Isolates from Artibeus lituratus previously characterized as $\mathrm{AgV}-4$ that were not segregated with the genetic lineage maintained by Tadarida brasiliensis population have been described ${ }^{27}$.

Although none of the studied samples belonged to haematophagous bats, the majority of the antigenic and genetic variants found were related to this bat species. This can be explained by the fact that haematophagous bats seem to be the most efficient source of propagation for rabies virus, as their feeding habits lead to attack different animal species, including other bats species in aggressive social interactions, sometimes ${ }^{28}$. It is very important to the actualization of new studies about biology and behavior of bats.

In a study conducted by Albas et al. ${ }^{30}$ on the prevalence of rabies virus in the studied region in the State of São Paulo from 1996 to 2003, 58 (78.4\%) of the 74 positive samples were isolated from non-haematophagous bats. This fact can be attributed to the results obtained by the Rabies Herbivorous Control Program (PNCRH) in Brazil ${ }^{31}$. The study of antigenic and molecular epidemiology of rabies aerial cycle is a very important tool to understand the possible relationships among the different species of bats as to the possibilities of transmission of the virus to other animal species and humans ${ }^{26}$. Moreover, well the necessity of studies with bat shelters to observe the biology and behavior of these animals and their participation in rabies transmission. This knowledge has an extreme importance in rabies prevention and control and must be stimulated in all regions in the State of São Paulo, Brazil.

\section{CONFLICT OF INTEREST}

The authors declare that there is no conflict of interest.

\section{FINANCIAL SUPPORT}

Fundação de Amparo à Pesquisa do Estado de São Paulo-FAPESP (Process 05/59818-6 and Process 07/01843-0).

\section{REFERENCES}

1. World Health Organization. WHO Expert Consultation on Rabies. WHO Technical Report Series 931. Geneva: World Health Organization; 2005 - [cited 2006 Ago 18]. Available from: http://www.who.int/rabies/trs931_\%2006_05. pdf.

2. Pringle CR. The Order Mononegavirales. Arch Virol 1991; 117:137-140.

3. International Committee on Taxonomy of Viruses [Internet]. [cited $2009 \mathrm{Dec} 17$ ]. Available from: http://www.ictvonline.org/virusTaxonomy.asp?version=2009.

4. Woldehiwet Z. Rabies: recent developments. Res Vet Sci 2002; 73:17-25.

5. Ministério da Saúde. Programa de vigilância controle e profilaxia da raiva. Brasília: Ministério da Saúde; 2010 - [cited 2010 Dec 11]. Available from: http://portal. saude.gov.br/portal/saude/profissional/area.cfm?id_area $=1567$.

6. World Health Organization. World survey of rabies N 32 for the Year 1996. Geneva: World Health Organization; 1996.

7. Organização Panamericana de Saúde (OPAS). Instituto Panamericano de Proteccion de Alimentos y Zoonosis (INPPAZ). Boletin Vigilância epidemiologica 1999; 31:27-34.

8. Arellano-Sota C. Biology, Ecology, and Control of the Vampire Bat. Reviews Infect Dis 1988; 10:S615-S619.

9. Mattos CC, Mattos CA, Loza-Rubio E, Aguilar-Setién A, Orciari LA, Smith JS Molecular Characterization of Rabies Virus Isolates from Mexico: Implications for Transmission Dynamics and Human Risk. Am J Trop Med Hyg 1999; 61:587-597.

10. Warner CK, Zaki SR, Shieh WJ, Whitfield SG, Smith JS, Orciari LA, et al. Laboratory investigation of human deaths from vampire bat rabies in Peru. Am J Trop Med Hyg 1999; 60:502-507.

11. Rosa EST, Kotait I, Barbosa TFS, Carrieri ML, Brandão PE, Pinheiro AS, et al. Bat-transmitted Human Rabies Outbreaks, Brazilian Amazon. Emerg Infect Dis 2006; 12:1197-1202.

12. Favoretto SR, Carrieri ML, Cunha EM, Aguiar EA, Silva LH, Sodre MM, et al. Antigenic typing of Brazilian rabies virus samples isolated from animals and humans, 1989-2000. Rev Inst Med Trop São Paulo 2002; 44:91-95.

13. Favoretto SR, Mattos CC, Morais NB, Carrieri ML, Rolim BN, Silva LM, et al. Rabies virus maintained by dogs in humans and terrestrial wildlife, Ceará State, Brazil. Emerg Infect Dis 2006; 12:1978-1981.

14. Dean DJ, Abelseth MK, Atanasiu P. The fluorescent antibody test. In: World Health Organization (WHO), editor. Laboratory techniques in rabies. $4^{\text {th }}$ ed. Geneva: WHO; 1996. p. 88-93.

15. Koprowski K. The mouse inoculation test. In: World Health Organization (WHO), editor. Laboratory techniques in rabies. $4^{\text {th }}$ ed. Geneva: WHO; 1996. p. 80-86.

16. Smith JS, Orciari LA, Yager PA, Seidel HD, Warner CK. Epidemiologic and historical relationships among 87 rabies virus isolates as determined by limited sequence analysis. J Infect Dis 1992; 166:296-307. 
17. Campos AC, Melo FL, Romano CM, Araujo DB, Cunha EM, Sacramento DR, et al. One-step protocol for amplification of near full-length cDNA of the rabies virus genome. J Virol Methods 2011; 174(1-2):1-6. Epub 2011, April 5.

18. Thompson JD, Gibson TJ, Plewniak F, Jeanmougin F, Higgins DG. The Clustal $\mathrm{X}$ windows interface: flexible strategies for multiple sequence alignment aided by quality analysis tools. Nucleic Acids Res 1997; 25:4876-4882.

19. Tamura K, DudleyJ, Nei M, Kumar S. MEGA4: Molecular Evolutionary Genetics Analysis (MEGA) software version 4.0. Mol Biol and Evol 2007; 24:1596-1599.

20. Diaz AM, Papo S, Rodrigues A, Smith JS. Antigenic analysis of rabies-virus isolates from Latin America and the Caribbean. J Vet Med 1994; 41:153-160.

21. Mattos CA, Mattos CC, Smith JS, Miller ET, Sara-Papo AV, Osburn BI. Genetic characterization of rabies field from Venezuela. J Clin Microbiol 1996; 34:15531558 .

22. Favi M, Nina A, Yung V, Fernandez J. Characterization of rabies virus isolates in Bolivia. Virus Res 2003; 97:135-140.

23. Kissi B, Tordo N, Bourhy H. Genetic polymorphism in the rabies virus nucleoprotein gene. Virology 1995; 209:526-537.

24. Kobayashi Y, Okuda H, Nakamura K, Sato G, Itou T, Carvalho AA, et al. Genetic analysis of phosphoprotein and matrix protein of rabies viruses isolated in Brazil. J Vet Med Sci 2007; 69:1145-1154.

25. Oliveira RN, Souza SP, Lobo RS, Castilho JG, Macedo CI, Carnieli Jr P, et al. Rabies virus in insectivorous bats: implications of the diversity of the nucleoprotein and glycoprotein genes for molecular epidemiology. Virology 2010; 405:352-360.

26. Favoretto SR, Mattos CC, Carrieri ML, Mattos CA, Cunha EMS, Aguiar EAC, et al. Rabies in chiropters: typification and epidemiological study. Paper presented at: The $10^{\text {th }}$ International Rabies in the Americas Meeting; 1999; San Diego-CA, USA.

27. Favoretto SR. Estudo das amostras isoladas em morcegos. In: Kotait I, Aguiar EAC, Carrieri ML, Harmani NMS, editors. Manejo de quirópteros em areas urbanas. Manual Técnico do Instituto Pasteur no 7 . São Paulo: Instituto Pasteur; 2003. p. 32-34.

28. Wunner WH. Rabies virus. In: Jackson AC, Wunner WH, editors. Rabies. $2^{\text {nd }}$ ed. San Diego: Academic Press; 2007. p. 23-68.

29. Almeida MF, Favoretto SR, Martorelli LF, Trezza-Netto J, Campos AC, Ozahata $\mathrm{CH}$, et al. Characterization of rabies virus isolated from a colony of Eptesicus furinalis bats in Brazil. Rev Inst Med Trop Sao Paulo 2011; 53:31-37.

30. Albas A, Souza EAN, Picolo MR, Favoretto SR, Gama AR, Sodré MM. Os morcegos e a raiva na região oeste do Estado de São Paulo. Rev Soc Bras Med Trop 2011; 44:201-205.

31. Ministério da Agricultura, Pecuária e Abastecimento. Controle da Raiva dos Herbívoros: Manual Técnico 2009. Brasília: Ministério da Agricultura, Pecuária e Abastecimento; 2009. 